Publishing Co., Westport, Connecticut. pp. 305 351.

20. National Research Council, Board on Agriculture. 1989. Alternative Agriculture. National Academy Press, Washington, D.C

21. Nilsson, T. 1979. Yield, storage ability, quality and chemical composition of carrot, cabbage and leek at conventional and organic fertilizing. Acta Horticulturae 93:209-223.

22. Parr, J.F., and D. Colacicco. 1987. Organic materials as alternative nutrient sources. In Z.R. Helsel (ed). Energy in Plant Nutrition and Pest Control. Elsevier Science, New York, N.Y.pp. 81-99.

23. Parr, J.F., R.I. Papendick, S.B. Hornick, and R.E Meyer. 1992. Soil quality: Attributes and relationships to alternative and sustainable agriculture. Amer. J. Alternative Agric. 7: 5-11.

24. Peavy, W.S., and J.K. Greig. 1972. Organic and mineral fertilizers compared by yields, quality and composition of spinach. J. Amer. Horticultural Sci. 97:718-723.

25. Power, J.F., and R.F. Follett. 1987. Monoculture. Scientific American 255(3):79-86.

26. Rendig, V.V. 1984. Soil fertility and plant nutrition effects on the nutritional quality of crops. In R.M. Welch and W.H. Gabelman (eds). Crops as Sources of Nutrients for Humans. Pub. No. 48. Soil Sci. Soc. Amer., Crop Sci. Soc. Amer., and Amer. Soc. Agronomy, Madison, Wisconsin.pp. 61-77.

27. Rodale, J.I. 1971. Pay Dirt. Rodale Press, Inc., Emmaus, Pennsylvania.

28. Salunkhe, D.K., and B.B. Desai. 1988. Effects of agricultural practices, handling, processing, and storage on vegetables. In E. Karmas and R.S. Harris (eds). Nutritional Evaluation of Food Processing. 3rd ed. Van Nostrand Reinhold, New York, N.Y. pp. 23-71.

29. Schuphan, W. 1972. Effects of the application of inorganic and organic manures on the marke quality and on the biological value of agricultural products. Qualitas Plantarum-Mater. Veg. XXI, 4:381-398.

30. Schuphan, W. 1974. Nutritional value of crops as influenced by organic and inorganic fertilizer treatments-results of 12 years' experiments with vegetables. Qualitas Plantarum-Plant Foods Hum. Nutr. 23:333-358.

31. Somers, G.F., and K.C. Beeson. 1948. The influence of climate and fertilizer practices upon the vitamin and mineral content of vegetables. Adv. Food Res. 1:291-324.

32. Svec, L.V., C.A. Thoroughgood, and H.C.S. Mok. 1976. Chemical evaluation of vegetables grown with conventional or organic soil amendments. Commun. Soil Sci. Plant Anal. 7(2):213 228.

33. Thonney, P.F., and C.A. Bisogni. 1989. Residues of agricultural chemicals on fruits and vegetables: Pesticide use and regulatory issues. Nutrition Today 24(6):6-12

34. U.S. Dept. of Agric. 1980. Report and Recommendations on Organic Farming. U.S. Government Printing Office, Washington, D.C.

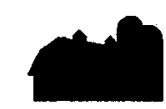

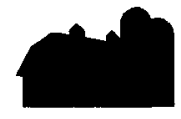

LETTERS

\section{Institutional/sociological links between sustainable agriculture and wildlife need further examination}

As Ann Robinson correctly stated, wildlife managers and advocates of sustainable agriculture share "a great deal of common ground" (AJAA 6(4), 161-167). While the article's conclusion that "wildlife and fish habitat will be greatly enhanced if the movement toward more sustainable methods of farming becomes widespread" may be accurate in a general way, it fails to recognize the technical, institutional, and sociological complexity inherent in wildlife management. The connection between agrichemical usage and habitat degradation is an important linkage to recognize, but failure to place this issue and the others Robinson mentions in the context of a system is a failure to identify the "wildlife connection." I do not claim to have all of the answers; I simply write to express my views on a subject that is important to me.

Máking changes in farming systems (e.g., decreased field size, altered hay cutting schedules) will benefit some wildlife species, but possibly at the expense of other species and possibly at a cost to the producer or the public. The trade-offs inherent in manipulating factors that affect wildlife and farm operations must be undertaken with clear goals in mind. The most important goal is what wildlife species you wish to manage for. It is extremely unlikely that in heavily farmed regions, there is sufficient area to manage in such a manner that every species will be given a leg up, so to speak.

As Robinson states, supporting resilient wildlife populations involves reduced loading of pollutants to natural systems.
But the strategy must do more than that. The holism inherent in systems thinking and in sustainable agriculture is where the "wildlife connection" lies. I see five major areas on which we must focus to insure wildlife's future in agricultural landscapes.

1. Policy at both national and state levels must be made functional in terms of simultaneously supporting specific wildlife management objectives and profitable farming. Converting marginal (highly erodible) cropland to land that provides services to wildlife (Conservation Reserve Program) is a major opportunity. Another area of importance is the acreage flexibility provisions that relax disincentives to adoption of "innovative" farming practices such as crop rotation.

2. Federal and state agencies that traditionally have not worked closely together, such as state Departments of Agriculture and state Departments of Natural Resources, must continue current efforts to become more fully integrated by supporting cross-departmental training, open communication channels, and standardization of functions such as data collection and storage. Through enhanced institutional integration of this type, wildlife managers and the agricultural community can more effectively identify and capitalize on opportunities for mutual gains.

3. Lands that possess particular characteristics in terms of relative location or suitability for wildlife should be strategically targeted and managed to provide for the needs of specific wildlife species. In many situations the most economical way to pursue this important step is to develop farming systems (i.e., Best Management Practices) that are acceptable to producers and that provide minimum threshold habitat requirements. This approach 
would keep land on the local tax roles, reinforce land stewardship as the purview of the American farmer, and avoid heavy public expenditures. In certain situations, however, acquisition or consultative land management via easements or lease agreements probably will be necessary. In such cases, the public must understand what they are buying and why.

4. Woodlot management and private forestry should be aggressively promoted and coordinated, at the landscape scale, to provide benefits to specific wildlife species. Current programs such as Forest Stewardship, the Tree Farm program, and differential property tax treatment of forested tracts could be greatly enhanced by efforts to help forest land owners obtain higher stumpage prices. Investment in forest management will follow if landowners are in a position to capture the value of their trees. However, forest cover is not universally compatible with all wildlife management goals and may not be appropriate under all circumstances.

5. Educational programming based on research must be made available to both urban and rural citizenry regarding the "wildlife connection." Practices that favor targeted wildlife species should be incorporated into State Cooperative Extension recommendations. Efforts to include wildlife management courses in the curricula of all students of natural resource disciplines should be continued.

The five items listed above represent the tools that are required to provide a place for wildlife in agricultural landscapes, but what about the process? To plan for wildlife in an agricultural landscape, I see the following steps as important:

We first need to know what we hope to accomplish. What species do we want to support?

Then we need to know how to attain this goal. What components of the environment should we manipulate? How much habitat, of what quality, will be needed?
What types of Best Management Practices are likely to be compatible with the equipment, labor supply, managerial skill, goals, and values of land owners, while providing the essentials for animals to survive and reproduce?

We then will need a way of conceptualizing and predicting how manipulations we undertake will affect the environment and farm operations.

Finally, we should be prepared to monitor our progress and make changes to the program if indicated.

To portray wildlife as the beneficiary of reduced agrichemical usage and other changes in cropping systems represents a failure to capitalize on what I consider the strength of sustainable agriculture--cognizance of the interrelationships among technology, institutions, people, and the environment, and the ability to solve problems from such a position.

\section{Steven Wolf \\ Graduate Student \\ Department of Rural Sociology \\ University of Wisconsin \\ Madison, WI 53706}

\section{Response:}

Steven Wolf seems to be suggesting further examination of the institutional/sociological links between sustainable agriculture and wildlife. I do not view this as a refutation of my original discussion, but as complementary. In presentations and in other articles, I have made similar points, but in this article I chose a different focus. Nevertheless, I am wary of the underlying tone here. Some of these arguments sound much like those I have heard in the past from defenders of conventional agriculture, forestry, and wildlife approaches.

Mr. Wolf suggests the need to develop "farming systems (i.e., Best Management Practices) that are acceptable to producers and provide minimum threshold habitat requirements." The implications are that sustainable farming will not be acceptable or economically profitable, and that it will remove land from local tax roles, etc. I question such assumptions. Certainly, a growing body of research and demonstration indicates that sustainable farming (which goes beyond BMPs) is practical, profitable and offers many positive alternatives for farmers, communities, and consumers.

In addition, Mr. Wolf insists that in tracing the wildlife-farming connection, the first step "and most important goal" should be to identify which wildlife species one wishes to support. Of course, setting goals is important, since species have different habitat requirements and one must also decide the level of scale to target, whether it is the farm, the region, or the nation. However, the longtime practice of managing for one or a few species, usually "game" species, is rapidly going out of favor as being too limited. This approach has often led to a plethora of the managedfor animal, while all around, species filling other niches disappear. When this happens, landscapes become less resilient, less bountiful, and less beautiful. In place of an approach that targets species, many in the wildlife management community are moving towards methods that seek to foster biodiversity. Biodiversity depends on the restoration of functioning ecosystems that will once again support a wide variety of species that dwell in the soil, on the land, and in the water.

\author{
Ann Y. Robinson \\ Agricultural Specialist \\ Izaak Walton League of America \\ 801 Commerce Drive \\ Decorah, IA 52101
}

